\title{
From Alpha to Omega: Ancient Mysteries and the Near-Death Experience
}

\author{
Kenneth Ring \\ Department of Psychology \\ University of Connecticut
}

\begin{abstract}
The Osirian temple rites of ancient Egypt may have involved ceremonial procedures deliberately calculated to induce an experience that was functionally identical to modern near-death experiences (NDEs). In that way, initiates into those Mysteries were enabled to discern for themselves the fundamental teaching of many of the Wisdom Schools of antiquity that there is no death-which also represents the almost universal conviction of today's NDErs. In addition to exploring apparent parallels between these Osirian initiations and NDEs, certain important and possibly critical differences are also discussed.
\end{abstract}

It was philosopher Michael Grosso who one evening several years ago in conversation impressed upon me the importance of the connection between the mystery rites of antiquity and the near-death experience (NDE). Grosso, who has since written about this point (1983), emphasized for example that in the most famous of the Greek mysteries, those at Eleusis, the initiates into what are known as the Greater Mysteries (Kerenyi, 1977; Taylor, 1980) may well have undergone a psychedelically assisted death-and-rebirth experience akin to an NDE. Later, Grosso (1983) was even more certain of this hypothesis. In reviewing some of the classical literature pertaining to these rites, he concluded: "The ancient Greeks seem, in fact, to have worked out a fairly effective method for inducing a type of functionally equivalent near-death experience"' (pp. 24-25.)

Although my own work in near-death studies at the time of our initial conversation on this subject was entirely within a modern psychological context, my interest in the NDE since then has gravitated increasingly toward the kind of perspective Grosso, as a classical scholar, could articulate so well. In his ruminations about the NDE, he was already concerned with its larger historical and even mythic significance as well as its relevance for other fields of empirical inquiry, such as parapsychology. For my part, as a 
psychologist, I was then preoccupied with the basic parameters of the NDE as a type of transcendental experience and was only becoming aware of its profound after effects. Eventually, however, I found myself drawn to speculate about the possible role of the NDE in planetary transformation and human evolution (Ring, 1984a) and, most recently, have been led back to the Ancient Wisdom tradition itself in order to illuminate further the meaning of the NDE (Ring, 1984b).

Only now, I think, can I begin to appreciate more fully the ideas Grosso first outlined to me. They kindled a flame of sorts within me that evening that has been at least bright enough to allow me to grope my way through the literature on the ancient teachings ${ }^{1}$ until I reached the source of the Eleusinian mysteries themselves-in the perennially absorbing Osirian temple rites of pharaonic Egypt.

\section{THE EGYPTIAN MYSTERIES}

The origins of the mystery traditions in Egypt, like those of its colossal pyramids, are likely to remain forever obscure to us, but there is one highly relevant fact about what these initiations involved that in the view of many deep students of these rites (e.g., Adams, 1982; Brunton, 1984; Haich, 1974; Hall, 1975; Schwaller de Lubicz, 1978; Schure, 1971) seems incontestable: the candidate who successfully completed the trials comprising the supreme initiation came to know experientially that there is no death and that therefore his true self is immortal. Manly P. Hall (1982), for example, in a recent commentary, advanced this position as follows:

I think it is very important to bear in mind that the initiate system (in Egypt) was based upon one tremendous point ... -that the individual should learn ... through personal experience that death is an illusion ... The ancients ... developed a science by means of which they could communicate the fact and example and circumstance of death directly to another person. In other words ... the initiates of the Mysteries were persons who had lived, died and been born again in this world . . .

This was the burden of the Mysteri(es)-that the individual who knew, not because he could believe or have faith, but, because of the rites, ceremonies and esoteric practices of the temple, he lived through it and came through alive and came out of darkness into light (knowing) as a certainty beyond question that there was no death. (Hall, 1982)

Of course, nobody knows with certainty exactly how this "science" of death induction and resurrection of which Hall speaks was actually carried out by the hierophants of the Egyptian temples. And if we focus on that grandest symbol of the Mysteries-the Great Pyramid at Giza-which some scholars think was the site of the 
highest Osirian initiations, our uncertainty only increases. When the Caliph Al Mamoun, in search of fabulous treasure that many believed lay within the pyramid, penetrated into its interior in 820 A.D. and discovered its now famous passageways, he not only failed to find riches, he found, in effect, nothing. No art work adorned the corridors or the chambers; no hieroglyphics provided a basis for inferring what the inner structures of the pyramid were used for; no mummy was found to substantiate the view that this mighty temple was intended to be the enormous tomb of the pharaoh, Cheops. In the largest of the rooms then discovered, now called the King's Chamber, there was, it is true, one item of interest: an open stone coffin whose only occupant was the dust of the ages. Like its brother, the Sphinx, the Great Pyramid at Giza did not readily vouchsafe its secrets, especially to its defilers.

But, to be sure, we do have material evidence from other temples from which to reconstruct what might have taken place at the Great Pyramid itself. Hall, for instance, wrote that he knew what rituals were conducted in the King's Chamber and what its coffin was used for:

In the King's Chamber was enacted the drama of the "second death." Here the candidate, after being crucified upon the cross of the solstices and the equinoxes, was buried in the great coffer. There is a profound mystery to the atmosphere and temperature of the King's Chamber: it is of a peculiar deathlike cold which cuts to the marrow of the bone ${ }^{2}$. The room was a doorway between the material world and the transcendental spheres of Nature. While his body lay in the coffer, the soul of the neophyte soared as a humanheaded hawk through the celestial realms, there to discover first hand the eternity of Life, Light and Truth, as well as the illusion of Death, Darkness and Sin. Thus in one sense the Great Pyramid may be likened to a gate through which the ancient priests permitted a few to pass toward the attainment of individual completion. It is also to be noted incidentally that if the coffer in the King's Chamber be struck, the sound emitted has no known counterpart in any known musical scale. The tonal value may have formed part of that combination of circumstances which rendered the King's Chamber an ideal setting for the conferment of the highest degree of the Mysteries. (1975, p. 44)

There have, of course, been many attempts to reconstruct just what procedures were employed in the higher Osirian Mysteries and to imagine what their effects were on the candidate. Naturally, these accounts vary somewhat in their details and a great deal in their style (e.g., novelistic renderings by various writers steeped in the lore of Egyptian and other mysteries are a definite genre of their own in this field ${ }^{3}$ ), but on the essentials of these rites, and on their purposes, most commentators seem to be in general agreement. For 
my purposes, the version provided by Paul Brunton (1984), though nearly half a century old, is most instructive, so I will rely chiefly upon it in what follows.

\section{THE OSIRIAN INITIATION RITE}

Brunton's understanding of what he called "The mysterious drama of the innermost secret rite of Osiris" was based not only on his extensive travels in Egypt and his knowledge of the classical literature on this subject, but also on his own quite extraordinary experiences one night while alone in the King's Chamber of the Great Pyramid. According to his own account, at one point he found himself separated from his physical body and thereby absorbed some of the typical insights now commonly reported by today's near-death experiencers (Brunton, p. 75). Thus, Brunton's perpective on these sacred rites is rooted in direct personal knowledge as well as that gained by study and reflection upon cultural artifacts, discussion with other adepts, and his encyclopedic reading.

In any case, Brunton's formulation begins in complete accord with Hall's:

(This) august rite was nothing more or less than a process which combined hypnotic, magical and spiritual forces in an attempt to detach the candidate's soul from the heavy bondage of his fleshy body for a few hours, and sometimes for a few days, that he might ever after live with the memory of this epoch-making experience and conduct himself accordingly. The survival of the soul after death, accepted by most men through faith in their religion, he was thenceforth able to accept, strengthened in his conviction by the evidence of his personal knowledge. $(1984$, p. 84)

The whole purpose and purport of the initiation was to teach the candidate that "There is no death!" And he was taught this lesson in the clearest and most practical way possible, i.e., by being made to experience within himself the actual process of dying and mysteriously entering into another world of being. So deep was his trance that he was placed inside a painted and inscribed mummy-case whose lid was closed and sealed. To all intents and purposes, he had actually been murdered! (1984, p. 170)

In short, the initiate was made to identify with the Egyptian god of resurrection, Osiris, and experientially undergo Osiris's symbolic journey wherein after his death and the scattering of his body, he was reconstituted and brought back to life.

In the beginning of this journey, as with physical death itself, there could be terror. According to an ancient testimony, which Brunton claims is representative of this aspect of the experience, at the outset: 
"(T)he mind is affected and agitated in death just as it is in initiation into the Great Mysteries; the first stage is nothing but errors and uncertainties, laborings, wanderings and darkness. And now, arrived on the verge of death and initiation, everything wears a dreadful aspect; it is all horrors, trembling and affrightenment." (1984, p. 183)

But as the experience progresses and the death-trance takes hold, the imagery becomes paradisiacal and the feeling ecstatic. Thus, the above account continues:

"But this scene once over, a miraculous and divine light displays itself ... perfect and initiated they are free, crowned, triumphant, they walk in regions of the blessed.' (1984, p. 183)

Perhaps the entire experience can be made more vivid if we resort for a moment to one of the novelistic reconstructions, mentioned earlier, of this secret rite. Consider, for example, this imaginative picturing by Schure (1971), which is consistent with Brunton's summary to this point:

At dusk the priest of Osiris, bearing torches, accompanied the new adept into the lower crypt . . . In a corner was an open marble sarcophagus.

"No man," said the hierophant, "escapes death, and every living soul is destined to resurrection. The adept goes through the tomb alive, that afterward he may enter into the light of Osiris. Lie down, therefore, in this coffin and wait for the light!

The initiate lay down in the open sarcophagus. The hierophant extended his hand over him in blessing and the procession of initiates left the cave in silence. A little lamp placed on the ground flickeringly lights the four sphinxes which support the thick columns of the crypt. A choir of deep voices is heard, low and muffled. Where does it come from? It is the funeral chant! He is breathing his last; the lamp casts a final light, then it extinguished entirely. The adept is alone in the darkness. The coldness of the tomb falls upon him, freezing all his limbs. Gradually he experiences the painful sensation of death and falls into a lethargy. His life passes before him in successive scenes like something unreal and his earthly consciousness becomes more and more vague and diffuse. But as he feels his body disintegrate, the ethereal part, the fluid in his being, is disengaged. He enters into an ecstasy ... .

What is that shining, far distant point which appears imperceptible against the black background of the shadows? It is coming closer, it is growing larger, it is becoming a five-pointed star, whose rays include all the colors of the rainbow, and which shoots into the darkness discharges of magnetic light. Now there is a sun which attracts it into the brightness of its incandescent center . . . Then the ecstatic one feels flooded with a warm, caressing breeze. Having assumed strange forms, the cloud condenses and becomes a human figure, the figure of a woman, the Isis of the hidden sanctuary, but younger, smiling and radiant. A transparent veil is wrapped around her and her body shines through it. In her hand she holds a scroll 
of papyrus. She softly approaches, leans over the initiate lying in his tomb, and says, "I am your invisible sister; I am your divine soul, and this is the book of your life ..." (Schure, 1971, pp. 60-61)

Returning to Brunton now, he indicated that, in effect, what Schure gave to his adept at the very end of the passage just quoted was a feature of the very highest form of initiation during which, as Brunton put it,

The souls of men were not merely freed temporarily from their bodies in a condition of simulated death . . . but . . . were actually carried up to the loftiest spheres of being, to the realm of the Creator Himself ${ }^{4}$. In this marvellous experience the finite mind of man was drawn into contact with the infinite mind of his superior divinity .. . This fleeting contact of incomparable ecstasy was enough to change his entire attitude towards life. He had partaken of the holiest food that exists in life. He had discovered the ineffable ray of Deity which was his true innermost self, and of which the soul-body which survives death was merely the intangible vesture. He was, in verity and fact, born again in the highest sense. . . .

The doctrine of the immortality of the soul was more than a mere doctrine now; it was a proven fact, which had been completely demonstrated to him. When he awakened to the light of day, the initiate could truly say of himself that he had returned to the world completely transformed and spiritually reborn. $(1984$, pp. 187, 188)

In these excerpts, Brunton established not only what the candidate learned in the culminating phase of his initiation, but also that this direct knowledge had a deep impact on his character and orientation toward life. In this connection, he went on to assert that:

The Mysteries changed a man's attitude toward death and consequently altered his conduct toward life. (1984, p. 191)

And he quoted Diadorus, a native of Sicily, to the effect that:

It is said that those who have participated in the Mysteries became more spiritual, more just and better in every way. (1984, p. 185)

In conclusion, if we accept Brunton's understanding of the nature and purpose of the Osirian initiation rite, we see that the candidate, in entering the transcendental realm through death's door, comes back to life imbued with a spiritually enlightened attitude that finds direct expression in his daily conduct and relations with others. Hence, initiation generates transformation.

\section{THE NDE IN LIGHT OF THE OSIRIAN MYSTERIES}

Certainly no one familiar with the literature on the near-death 
experience could fail to notice the many parallels, both in phenomenology and aftereffects, between the Egyptian initiation and the NDE. It's obvious that if, as Grosso has observed, the Greeks had contrived their own means of inducing a kind of NDE in the Eleusinian Mysteries, the earlier Egyptians, whose entire culture revolved around death and resurrection, had provided them-and the world-with the ritual basis for inducing such states. And now it is equally clear that the Egyptian legacy has not just historical but contemporary relevance as well: the NDE is, in its essence, identical to what the Osirian candidate learned during his initiation ${ }^{5}$.

Nevertheless, my interest here goes beyond that of just drawing parallels between ancient rites and modern experience. I think that if we are properly to understand the significance of NDEs and their potential contribution to our planet's future, we need in fact not so much to dwell on the similiarities I have so far stressed, but to bring out some of the principal differences between the Mysteries of antiquity and the NDEs of today.

First, then, we must recall that in ancient times, the number of candidates who were initiated into the mysteries was really quite small and that the initiates themselves were highly selected. This contrasts with what, according to reliable estimates (e.g., Gallup, 1982), appear to be millions of NDErs, just in the United States alone (to say nothing of the vast number of NDErs elsewhere in the world), who can claim to know at least something of what the initiate of old experienced. Similarly, on the basis of demographic data (Gallup, 1982; Ring, 1984a), modern-day NDErs appear to be drawn from all strata of society without prejudice or obvious patterning. Thus, the elitism of Egyptian initiation has seemingly given way to the democratic spirit of our own era. The NDE is, as it were, an ecumenical experience.

Second, during the period of the Osirian Mysteries, the candidate had to undergo many prior trials and initiations and had to purify himself repeatedly before he was allowed to enter into the highest initiation where knowledge of immortality and one's essential divinity was disclosed experientially to him. In short, by the time of his supreme initiation, the candidate had been fully prepared for it. By contrast, the typical NDEr finds himself, willy-nilly, suddenly confronted by the onset of apparent imminent death, with no warning and certainly in most cases, little or no spiritual training of the kind that might provide some preparatory insight into the nature and implications of the NDE.

Third, we also must bear in mind that the initiate sought to be instructed, received his training and initiations over a long period 
of time from the priests and hierophants of the temple, and remained throughout embedded in a culture and context that gave meaning and coherence to his quest. The usual circumstance of today's NDEr could hardly be more different. His or her experience comes not through conscious choice, but as a direct consequence of unwanted illness or accident; the hierophants are the resuscitation team, which administers the modern equivalent of the initiation ceremony, CPR; the setting is the contemporary sterile hospital where illness is central and subjective experience an annoying distraction to be minimized or disregarded.

Finally, as is well known, the Osirian Mysteries remained mysteries because they were conducted in secret and the candidates were bound by a solemn oath not to divulge what they had seen and experienced. The penalty for violation of this sacred promise was death, as it also was for the initiates into the Greater Mysteries at Eleusis. In today's world, the "secret" of the NDE has not only been routinely revealed, but celebrated in countless articles and many books as well as on radio, television, and the motion picture screen. In short, the NDE has become a staple of our cultural fare, and about as secret as the local convenience store. And the "penalty" for disclosure, for both experiencer and researcher alike, is apt to be an invitation to "tell all" on the next available television talk show. One can only imagine the response of the ancients to these latterday developments.

Still, whether it was wise or otherwise, the "secret" is out, and the ancient mystery teachings, though in a corrupted form, have themselves been resurrected for the modern age. Millions of contemporary initiates have been inducted into today's version of the Osirian Mysteries and collectively they have brought a powerful and compelling message of hope that has now reached much of humanity. As a result, the idea of immortality has been empowered by a new, widespread and, apparently, credible experiential perspective - that of the NDE-and the symbol of light seems well on its way to replacing the spector of the Grim Reaper in our archetypal imagery of death itself.

Though we may have some feelings of disquiet over the way in which the Mysteries have returned in our time and some reservations about the uses to which they have been put, that they have reentered our cultural life in this vital way would not be surprising to at least a few of the students of these ancient rites. Hall (1975), for example, has written eloquently of his conviction that the teachings of antiquity would one day find a new glory and Brunton, more quietly, has expressed the same thought: 
The first great message of the ancient Mysteries- "There is no death," although always susceptible of personal experiential proof by a mere few, is destined to be broadcast to the whole world . . . (I)t is the writer's hope that conditions may be found, circumstances may be propitious, and the right persons forthcoming to plant a modern version, entirely altered to suit our changed epoch, of those mysteries once more in each of five continents of our world. (1984, pp. 191, 193-194)

Perhaps we may now have some reason to think that Brunton's hopeful prophecy is beginning to be realized in our own era, as a result, in part, of the collective testimony of NDErs. This, surely, is a tempting speculation and as much as I personally would like to endorse it, I feel obliged to sound a note of restraint in view of the very differences between ancient initiates and modern NDErs that I have already pointed out.

In my opinion, we must be mindful that most NDErs, however numerous they are and however much publicity they have received, are essentially neophytes on the spiritual path. Like most of the rest of us, they are still struggling to find their way and to reflect the light more fully. To be sure, they have seen and incorporated the light and there appears to be little doubt that, despite their lack of preparation for the NDE and its often difficult aftermath, many NDErs have been profoundly transformed by their experience (e.g., Ring, 1984a; Flynn, in press; Grey, in press). Similarly, there is every reason to think that the NDE is itself a powerful catalyst for spiritual awakening and development. At the same time, however, we must remember that precisely because most NDErs have been thrust into their initiation without either purification or preparation, they may bring back a somewhat distorted version of its essential insights or, even if that is not the case, be unable truly to appreciate its significance or conduct themselves in accordance with its spiritual implications. In a phrase, it is probable that in most NDErs there will be a mix of the gold of the NDE and the copper of the ego. In this light, it may be useful to view the NDE as an initiation in the sense of a beginning rather than, as it presumably was for the Osirian initiates, the culmination of a process of spiritual development and refinement.

If my own sense of caution here has any merit, it may also have the virtue of redirecting our attention once more to the ancient mysteries themselves in order to learn from them how best to cultivate and nourish the spiritual potential that the NDE seems to symbolize for us at this point in humanity's development. The few ancients knew what the modern multitudes are coming to know; and the teachings of the former, translated into a meaningful contemporary 
frame of reference, could well help us to avoid some of the pitfalls into which we might otherwise stumble in our attempt to honor the "inner teaching" of the NDE. A recent lesson in point that most readers will remember is the so-called "psychedelic revolution" of the '60s. Twenty years ago, millions of persons had also "seen the light" through psychedelic drugs, and some apostles of LSD began to prophesy that we were witnessing the advent of a new spiritual epoch in humanity's history that would transform and bring peace to the world. Psychedelics, as a class of drugs, were hardly new to the world scene at that time, of course; they had been used sacramentally in many cultures for hundreds, even thousands, of years. But when we used them recreationally, outside of a sacred ritual context, and became enchanted with "psychedelic gurus," we fell into a trap that we were never able to extricate ourselves from, and, twenty years later, the cloud of nuclear horror is darker than ever. It would be a shame-and it might possibly prove to be a disaster-if we were to allow ourselves to be similarly beguiled by the allure of NDEs and fail to discern and learn from the larger historical and spiritual matrix from which they spring. Only in that way, I believe, can we help to fashion something of a planetary cultural context, which we will need if we are ever to realize on a global scale the promise concealed within the NDE.

\section{THE PROMISE OF THE NDE: FROM ALPHA TO OMEGA}

What is the promise of the NDE?

In my last book, Heading Toward Omega (Ring, 1984a), I speculated that the NDE, because of its power of spiritual transformation, could have a significant role to play in accelerating human evolution toward a higher level of consciousness. Indeed, I argued that the millions of NDErs that modern technology has spawned, as well as millions of others who have had a similar spiritual transformative experience however it may have been brought about, might be regarded as the prototype of a more highly evolved type of human being now coming into manifestation for which I appropriated the term Homo noeticus. Others (e.g., Grosso, 1984; Grey, in press), while not necessarily agreeing with my own formulation of this evolutionary hypothesis, have also discerned in the NDE the seed of a higher humanity.

Though this hypothesis derives from today's near-death research, it is now apparent to me that it was also inherent in the lessons of the ancient mystery teachings themselves. For example, Paul Brunton averred: 
The experience of initiation was a miniature duplicate of the experience which was destined to become that of the whole human race, through the processes of evolution-the sole difference being that, as the former was a forced hurried growth, an artificial process like entrancement was employed, whereas with the latter both psychic and spiritual development would proceed naturally.

Thus the experience repictured within the soul the entire drama of human evolution, the ineluctable fate of human beings. (Brunton, 1984, pp. 187-188)

Hall (1951) also expressed a similar view when speaking of the mystic and the power of the mystical experience itself:

It would be most helpful if at this time psychologists and other specialists in the field of man's internal phenomena would consider the possibility that the mystic is the prototype of future humanity . . .

And again:

Is not mysticism the normal extension of growth pressing on toward the production of superior types of beings? . . . It is the mystic . . . who will be the superman of tomorrow. (1951, pp. 188, 189)

Hall posited a process of growth and spread for the mystic that is virtually identical to what I propose for the mystic malgre lui, the NDEr:

The operations of Nature nearly always manifest first by producing isolated examples of processes later to become general. These apparent anomalies gradually increase in number until they establish the new norm. In this way the exceptional is slowly transformed into the usual and acceptable. (1951, p. 192)

Thus, the Alpha of the ancient mysteries implies the same ultimate evolutionary destiny as does the Omega hypothesis of modern neardeath studies. In this understanding, whether we are describing the initiation process in a temple crypt or in an operating room, we are talking about a divine human potential with the inherent power to spiritualize the individual and his world.

With the spread of the modern form of the mystery teachingsthrough the NDE-and as more individuals personally survive this initiation and thus contribute further to the dissemination of these teachings, another opportunity presents itself for the spiritual regeneration of humanity.

Nevertheless, we cannot expect that this outcome will occur automatically or that it will necessarily approach fulfillment in the short run. Our "ultimate evolutionary destiny" is one thing; whether 
we or our children will even survive into the twenty-first century is another matter. To increase the chances of bringing the NDE seed to harvest any time soon, we will need to align ourselves fully and consciously with the spiritual forces of our own age as well as to learn from those masters of wisdom of earlier times whose teachings have endured.

Finally, as my friend Michael Grosso recently (1984) advised us, it comes down to what each of us is prepared to do to understand the mystery of ourselves. I end as I began, indebted to Michael Grosso, whose closing words in response to a previous article of mine suit my purposes as well as they did his:

One place the ancient archetype of the Western overself returns with all the force of the repressed is the hospital deathbed. Amid the scene of ritual resuscitation where, unfortunately, there are no hierophants, no guides, no one to help tease out the meaning of the experience from the afterglow of memory, there the mythology of death and enlightenment comes to life, powerful as old, flashing with transforming light, the heights and the abysses all intact. But probably for the great majority, and it would seem we are talking of millions now, one has to say with T. S. Eliot: "we had the experience but missed the meaning." Near-death researchers are helping to resuscitate the meaning and to decipher the Rosetta stone of the psyche's ancient mysteries.

Still there is no reason to cheer too loudly. Meaning is always born in an individual creative act, a deed as solitary as dying. In the present age each of us must create his own myth . . . (A)t least near-death researchers can go on sharing their findings, setting them out as raw material, as a resource for anyone interested in self-exploration, who wants to build his own myth of death. Every person's life is a mystery ritual, and it may be the mark of the new age to come that every person will have to be his or her own hierophant. (Grosso, 1984, pp. 160-161)

If indeed we are heading toward Omega, it will not be a free ride. We shall have to work to get there, beginning with the never-ending work on ourselves.

\section{NOTES}

1. I wish to thank Mineda J. McCleave for her invaluable guidance in directing me to some key references here.

2. Hall is not just repeating hearsay; he himself entered the King's Chamber in connection with his personal explorations of the pyramids.

3. For representative and engrossing examples of this kind of reconstruction, see Haich, 1974; Schwaller de Lubicz, 1978; and Schure, 1971.

4. In the first part of this passage Brunton is alluding to the common 
understanding that the spiritual aspirant underwent successive degrees of initiation that disclosed to him progressively "higher" truths. Thus, in the first initiation, the candidate learned the "truth" of personal survival; in the final initiation, he experienced contact with the Creative Force of the universe itself. These degrees of initiation appear to correspond to different levels of depth in contemporary near-death experiences.

5. In John White's opinion, it would be more accurate to say that the near-death experience approximates the essence of the first initiation (see footnote 4, above). (White, personal communication, Feb. 27, 1985).

\section{REFERENCES}

Adams, W. M. The Book of the Master of the Hidden Places. Wellingborough, England: Aquarian Press, 1982. (originally published 1933)

Brunton, P. A Search in Secret Egypt. New York: Samuel Weiser, 1984. (originally published 1936)

Flynn, C. P. Love Project. Englewood Cliffs, NJ: Prentice-Hall, in press.

Gallup, G., Jr. Adventures in Immortality. New York: McGrawHill, 1982.

Grey, M. Return from Death. London: Rutledge \& Kegan Paul, in press.

Grosso, M. Jung, parapsychology, and the near-death experience. Anabiosis, 1983, 3, 3-38.

Grosso, M. Self, eternity, and the mysteries. Anabiosis, 1984, 4, 153-161.

Haich, E. Initiation. Palo Alto, CA: Seed Center, 1974.

Hall, M. P. The Mystical Christ. Los Angeles: Philosophical Research Society, 1975.

Hall, M. P. (speaker). The Secret Teachings of All Ages. Los Angeles: Philosophical Research Society, 1975.

Hall, M. P. Initiation in the Pyramid (audiocassette). Los Angeles: Philosophical Research Society, 1982.

Kerenyi, C. Eleusis. New York: Schocken Books, 1977.

Ring, K. Heading Toward Omega. New York: William Morrow, 1984a.

Ring, $\mathrm{K}$. The nature of personal identity in the near-death experience. Anabiosis, 1984b, 4, 3-20.

Schure, E. The Mysteries of Ancient Egypt. Blauvelt, NY: Rudolf Steiner Publications, 1971. 
Schwaller de Lubicz, I. Her-Bak: Egyptian Initiate. New York: Inner Traditions International, 1978.

Taylor, T. The Eleusinian and Bacchic Mysteries. San Diego: Wizards Bookshelf, 1980. (originally published 1875)

Requests for reprints to:

Kenneth Ring

Department of Psychology

University of Connecticut

Storrs, Connecticut 06268 